\title{
Life Cycle Greenhouse Gas Emissions from
}

\section{Uranium Mining and Milling in Canada:}

\section{Supporting Information}

\author{
AUTHOR NAMES
}

David J. Parker*', Cameron S. McNaughton ${ }^{*+t}$, Gordon A. Sparks ${ }^{*}$

\section{AUTHOR ADDRESS}

$\dagger$ Department of Civil and Geological Engineering, University of Saskatchewan, Saskatoon, Saskatchewan S7N 5A9, Canada

† Golder Associates Ltd., Saskatoon, Saskatchewan S7H 0T4, Canada 


\section{Table of Contents}

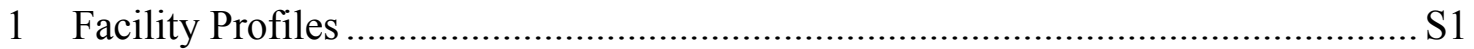

1.1 McArthur River Operation-Key Lake Operation (Cameco)...................................... S2

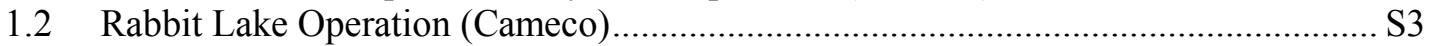

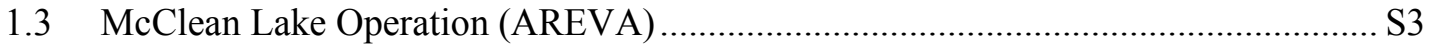

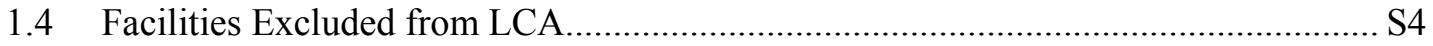

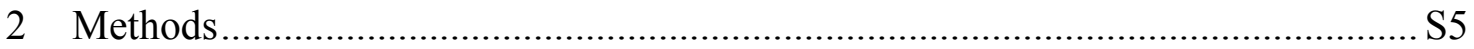



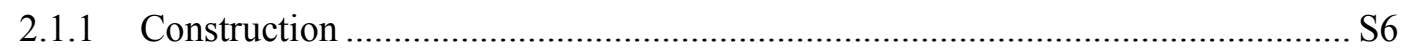

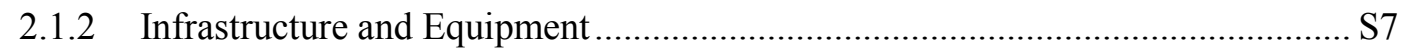

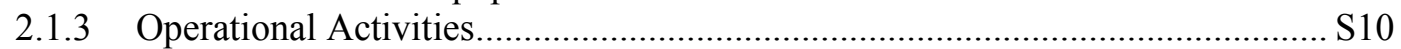

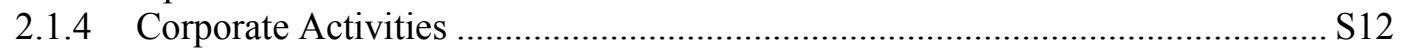

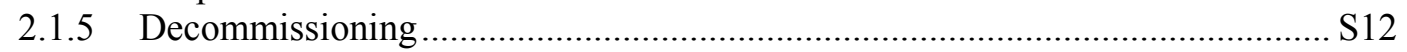

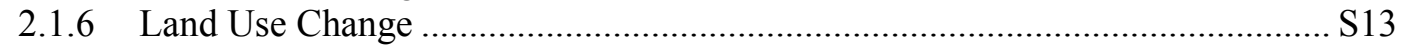

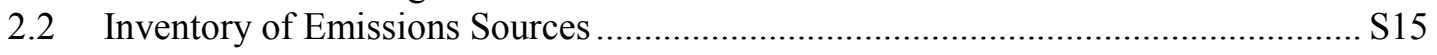

2.3 Emission Factors ......................................................................................... S16

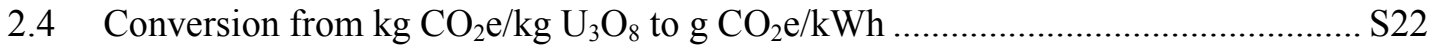



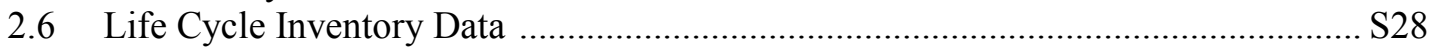

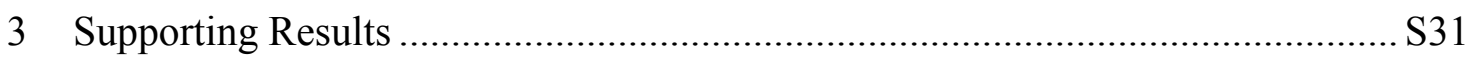

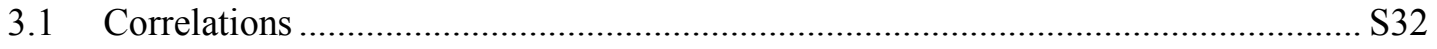

List of References for Supporting Information .............................................. S34 


\section{Tables and Figures}

Figure S1. Map of Major Uranium Deposits, Mines, and Mills in Saskatchewan ....................... S1

Figure S2. Indicator Score Range and Definitions Used in Assessing Uncertainty Factors ....... S26

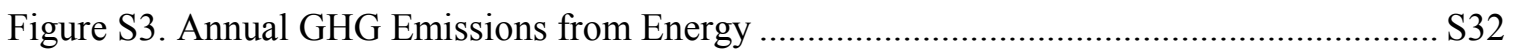

Figure S4. Annual GHG Emissions from Reagent Consumption ............................................. S33

Table S1. Additional Materials and Equipment Included in Analysis ......................................... S9

Table S2. Operational Data Requested and Received ....................................................... S1

Table S3-6. Major Emission Factors Used in This Study ..................................................... S18

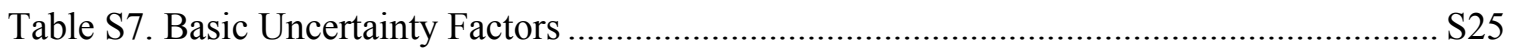

Table S8. Elemental Factors Used in Assessing Total Uncertainty Factor ............................. S26

Table S9. Life Cycle Inventory Data Including Uncertainty................................................ S29

Table S10. GHG Emissions Intensity $\left(\mathrm{kg} \mathrm{CO}_{2} \mathrm{e} / \mathrm{kg} \mathrm{U}_{3} \mathrm{O}_{8}\right)$ by Facility and Process ................... S31 


\section{Facility Profiles}

This study includes a detailed analysis of life cycle greenhouse gas (GHG) emissions during the uranium mining-milling phase of the nuclear fuel cycle for three paired mining-milling operations in northern Saskatchewan (SK), shown in Figure S1. These facilities are operated by AREVA Resources Canada Inc. (AREVA) and Cameco Corporation (Cameco).

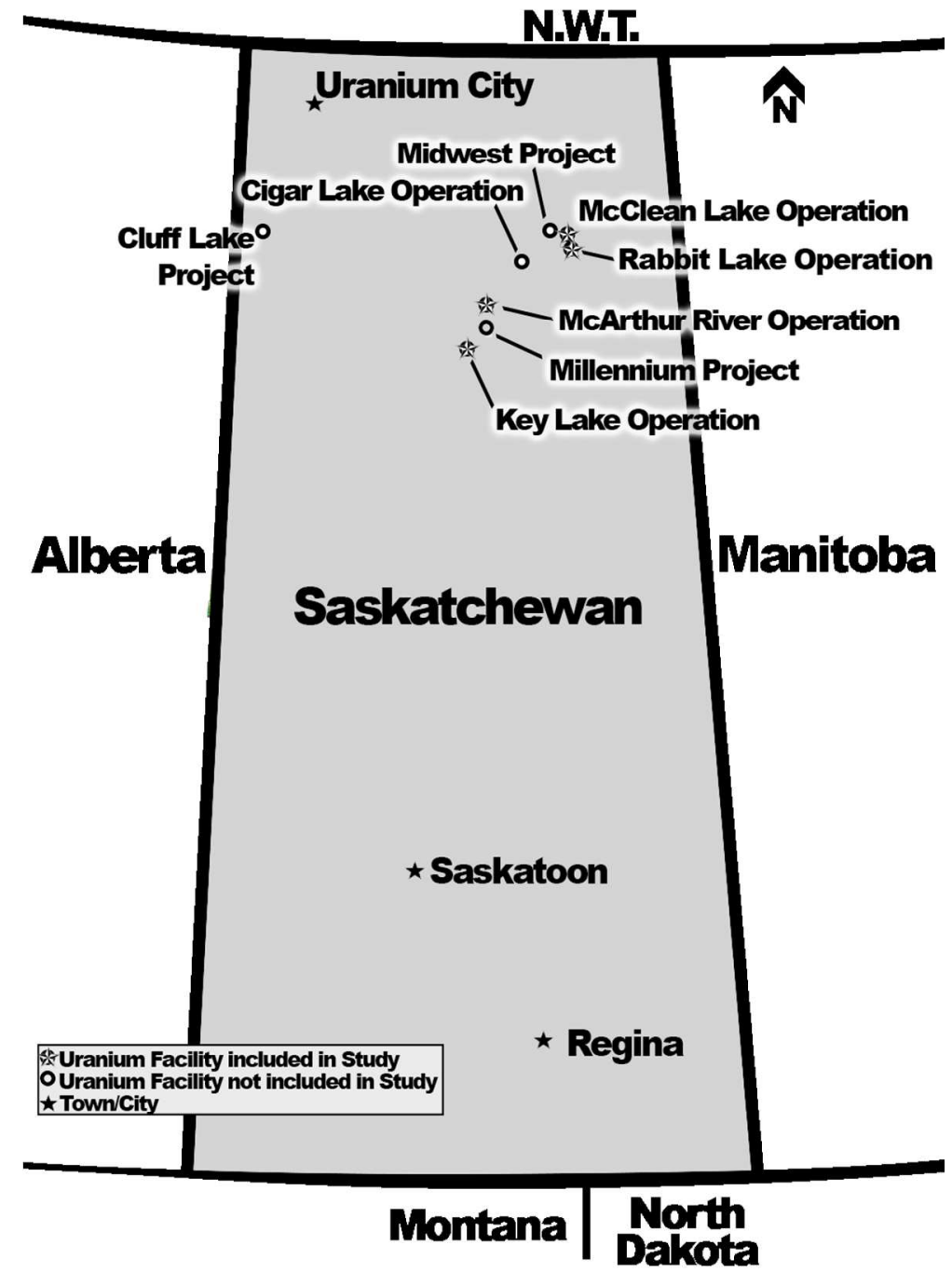

Figure S1. Map of Major Uranium Mines and Mills in Saskatchewan 


\subsection{McArthur River Operation-Key Lake Operation (Cameco)}

This study includes data from operation at McArthur River-Key Lake from 2006-2013 inclusive. For some processes, data outside of this temporal boundary was available and was also included.

McArthur River Operation (McArthur River) is located approximately $600 \mathrm{~km}$ north of Saskatoon by air and $790 \mathrm{~km}$ north by truck. ${ }^{1}$ Mining began in $1999 .{ }^{2}$ Ore is processed underground yielding a slurry which is pumped to surface, loaded into specially designed containers, and trucked to the Key Lake mill. ${ }^{2}$

As of Dec. 31 2013, a total of 114,195,511 $\mathrm{kg} \mathrm{U}_{3} \mathrm{O}_{8}$ had been produced at McArthur River and as of that date, proven and probable reserves of 163,519,142 $\mathrm{kg} \mathrm{U}_{3} \mathrm{O}_{8}$ remain. According to the current life-of-mine plan, ore reserves will be exhausted in the 2030's, depending on future production rates. ${ }^{2,3}$ Total reserves and mine lifespan are updated annually.

Key Lake Operation (Key Lake) is located approximately $570 \mathrm{~km}$ north of Saskatoon by air and $710 \mathrm{~km}$ by truck 1 . It began production in 1983, milling ore from the Gaertner and Deilmann open pits until 1997. ${ }^{4}$ From 1983-2000, Key Lake shipped 78,492,376 kg $\mathrm{U}_{3} \mathrm{O}_{8}$ sourced mainly from the Gaertner and Deilmann pits. In 2000, the Key Lake mill began to process ore from the McArthur River deposit, $72 \mathrm{~km}$ away by truck. ${ }^{4}$ From 2000-2013, Key Lake shipped 77,737,681 $\mathrm{kg} \mathrm{U}_{3} \mathrm{O}_{8}$ sourced mainly from McArthur River. ${ }^{5}$ Assuming that Key Lake processes the remaining reserves of McArthur River's uranium at an average recovery rate of $98.5 \%$, it will ship another $161,000,000 \mathrm{~kg} \mathrm{U}_{3} \mathrm{O}_{8}$. 


\subsection{Rabbit Lake Operation (Cameco)}

The Rabbit Lake facility began operation in 1975 and is: "the longest operating uranium production facility in North America, and the second largest uranium mill in the world." ${ }^{6}$ It is located approximately $670 \mathrm{~km}$ north of Saskatoon by air and $820 \mathrm{~km}$ by truck. $^{1}$

Rabbit Lake Operation (Rabbit Lake) mill has previously obtained ore from Rabbit Lake open pit, Collins Bay A- B- and D- zones, and currently receives ore from Eagle Point underground mine using a drill and blast method. ${ }^{4}$ From 1975-2013, Rabbit Lake produced $86,227,910 \mathrm{~kg} \mathrm{U}_{3} \mathrm{O}_{8}$ and additional production of $8,800,000 \mathrm{~kg} \mathrm{U}_{3} \mathrm{O}_{8}$ is expected from 2014-2018. ${ }^{7,8,9}$ This study includes data from operation at Rabbit Lake from 2006-2013 inclusive.

\subsection{McClean Lake Operation (AREVA)}

McClean Lake Operation (McClean Lake) began in 1995 with the mining of JEB open pit and the construction of the JEB Mill. AREVA claims that McClean Lake is the most technologically advanced uranium mill in the world, capable of processing ore from grades of less than $1 \%$ to $30 \%$ without dilution. ${ }^{10}$ It is located approximately $700 \mathrm{~km}$ north of Saskatoon by air and $830 \mathrm{~km}$ by truck. ${ }^{1}$

From 1995-2008, five open pits were mined out and the mill processed their ore from 1999-2010. During this time, approximately $22,700,000 \mathrm{~kg} \mathrm{U}_{3} \mathrm{O}_{8}$ was produced. ${ }^{11}$

In 2005 , the mill began an expansion project to increase its production capacity and allow it to receive ore from Cigar Lake underground mine, the world's largest undeveloped high-grade uranium mine. In July 2010, the mill shut down as uranium stockpiles were depleted and expansion activities continued. ${ }^{11}$ This study includes data 
from operation at McClean Lake from the beginning of construction until the depletion of ore stockpiled from onsite open pits, i.e., 1995-2010 inclusive.

The McClean Lake mill began processing ore from Cigar Lake in 2014 and is expected to process all of Cigar Lake's $98,300,000+\mathrm{kg} \mathrm{U}_{3} \mathrm{O}_{8} .{ }^{11,12}$

\subsection{Facilities Excluded from LCA}

In addition to the above-mentioned facilities, AREVA has provided details for the decommissioning of Cluff Lake Project (Cluff Lake), an operation that included underground and open pit uranium mines as well as a uranium mill. Mining and milling at Cluff Lake ended in 2002 and decommissioning activities began soon after. In 2013, the last buildings were demolished and site occupancy ceased. Active decommissioning is now complete and the site is in a period of long-term monitoring. ${ }^{13}$ Cluff Lake Project is not considered for detailed analysis due to a lack of operational data. However, the recent decommissioning activities are used to help validate estimates of GHG emissions for decommissioning for the facilities considered as part of this study.

Cigar Lake Project (Cigar Lake) is a high-grade underground uranium mine located 69 $\mathrm{km}$ south of the McClean Lake mill, where ore slurry from the project will be shipped and processed. ${ }^{12}$ The mine began construction in 2005 and its first shipment of ore slurry arrived at McClean Lake mill in March 2014. ${ }^{12,14}$ Cigar Lake is expected to reach fullscale production in 2018. ${ }^{14}$ Like Cluff Lake, this facility is not considered for detailed analysis due to lack of operational data.

Two other major uranium projects, the Midwest Project and the Millennium Mine Project, are under development in SK but are not yet under construction. They too are excluded from analysis. 
Historical uranium projects in SK include Gunnar Mine (1955-1963), Lorado Mill (1957-1960), and Eldorado Mine (1953-1982). ${ }^{15,16}$ These are excluded from analysis because of lack of data and because they do not reflect the current practices employed by the Canadian uranium mining and milling industries.

2 Methods

\subsection{Data Collection}

The mine-mill operators, AREVA and Cameco, have collaborated in this research by providing multiple years of data related to emissions-relevant activities including energy consumption, reagent consumption, transportation, mining and milling processes, facility history, infrastructure, and more. Additional data was obtained from the ecoinvent life cycle database. ${ }^{17}$

It is assumed that all data provided by the mine-mill operators is accurate and has been validated by each company's internal auditing program. Unless otherwise stated, data from the operators is not explicitly validated as part of this study.

Where data was not available, assumptions were made to fill information gaps. The associated uncertainty is assessed according to the methodology discussed in Section 2.5. The following sections note specific instances where the methodology employed deviates from that described in Section 2.5. Activity factors for most major processes along with their associated uncertainty are shown in Section 2.6, Table S9.

The life cycle approach requires the consideration of construction, operation, and decommissioning activities as well as emissions embodied in infrastructure, equipment, and materials. 


\subsubsection{Construction}

Construction activities include the transport of construction materials and employees to construct buildings, earthworks, and roads. At uranium mining facilities, it also includes development of the open pit or underground mine.

Since most construction activities occurred before the operating companies had begun systematically assessing and reporting their energy consumption and GHG emissions, there are no accessible records for early construction activities. In the absence of this data, emissions are estimated by comparison with similar facilities for which data or qualified estimates are available.

Energy consumption data during construction of McClean Lake Operation is partially available. Construction activities at McClean Lake include development of both the open pit mines and the uranium mill. Similar activities were undertaken in the development of both Rabbit Lake and Key Lake mills, both of which originally had open pit mines. ${ }^{18}$ Data from McClean Lake is used to anchor emission estimates for direct and indirect energy consumption at these facilities.

Cigar Lake is an underground uranium mine with some similarities to McArthur River including a freezing program, the use of mining techniques that isolate employees from contact with high grade ore, and an ore crushing and grinding circuit located in the underground facility. ${ }^{12}$ Some site-specific factors complicate the comparison of the two facilities, most notably setbacks at Cigar Lake resulting from three water inflow incidents between 2006 and 2008. ${ }^{12}$ Data for energy consumption and employee transport for Cigar Lake are available for nine years. ${ }^{19}$ The construction estimate for McArthur River 
is informed by emission from Cigar Lake during this period, but also takes into account the differences between the projects.

Millennium Project is a proposed underground mine located approximately $600 \mathrm{~km}$ north of Saskatoon, midway between Key Lake and McArthur River. 20 GHG emission estimates for each production phase are provided in the project Environmental Impact Statement for two scenarios: 1) electricity provided to site in year two through decommissioning; and 2) electricity is not provided to site through life of mine. ${ }^{20}$ Cameco states that the emission estimates are highly conservative. ${ }^{20}$ These data are not used directly to estimate emissions for any of the facilities included in this study, as it is not directly comparable to any of those included. Rather, the Millennium EIS data were used to check the validity of the construction emissions estimates used in the current study.

The methods used to calculate emissions from direct and indirect energy consumption during the construction phase at these facilities introduces uncertainty to the calculated result. This uncertainty is included and calculated as described in Section 2.5.

\subsubsection{Infrastructure and Equipment}

It is not possible to directly assess all of the materials present in each building and piece of equipment. However, a rigorous LCA using PCA requires these quantities to be estimated.

Estimates for materials used in the structure of buildings are based on the area and volume occupied by buildings at each site. For Cameco facilities, this information is available in the Preliminary Decommissioning Plans. For AREVA facilities, building area is estimated from site layout drawings found in annual regulatory reports. Building 
heights for AREVA facilities are estimated based on similar buildings at Cameco sites and on observations made during a site tour. The mass of steel, aluminum, etc. used in the building structure per building unit volume are taken from ecoinvent Centre. ${ }^{17}$

Stationary equipment consists mostly of tanks, pipes, pumps, and hoists. Material types are listed in construction drawings, and mass in tanks and pumps are estimated based on their geometry as presented in engineering drawings. Tanks are modeled as cylinders, cones, and/or right rectangular prisms. Tanks are assigned a nominal wall thickness of $6.4 \mathrm{~mm}$. Where tanks are rubber lined, the lining is assigned a nominal thickness of $3.2 \mathrm{~mm}$. Pumps are modeled as solid steel cylinders. Material estimates based on these are then increased by $40 \%$ to account for other equipment such as cranes, ladders, stairs, piping, etc. The material estimate is further increased by $10 \%$ to account for equipment replacement.

For facilities where construction drawing were not available, materials usage is estimated. Based on the amount of materials used in the Key Lake mill, a material intensity is developed:

$$
\begin{aligned}
\text { Material Intensity }\left(\frac{\mathrm{kg} \text { material }}{\mathrm{m}^{3} \text { building }}\right) \\
=\frac{\text { Total Materials Estimated from Drawings }(\mathrm{kg})}{\text { Total Volume of Facility }\left(\mathrm{m}^{3}\right)}
\end{aligned}
$$

Material estimates for buildings without drawings are then generated based on applying this material intensity to the building's known volume: 


\section{Material Estimate = Material Intensity \\ $\times$ Building Volume $\times$ Intensity Factor}

The intensity factor varies between 0 and 1 depending on the relative amount of equipment in a building compared to the Key Lake mill buildings. An intensity factor of 1 indicates that the building has a similar amount of equipment in it as a mill building whereas an intensity factor of 0 describes an empty building. The choice of this factor is based on the activities undertaken in these buildings and also on information gathered during site tours.

In addition to the equipment and materials discussed above, the items listed in Table S1 are also included for analysis.

Table S1. Additional Materials and Equipment Included in Analysis

\begin{tabular}{lcc}
\hline & \multicolumn{2}{c}{ Data Source } \\
& $\begin{array}{c}\text { McArthur River, Key } \\
\text { Lake, Rabbit Lake }\end{array}$ & McClean Lake \\
\hline Materials & & $*$ \\
Concrete in Foundations & $(1)$ & $*$ \\
Polyethylene Piping around Site & $(1)$ & \\
Fuel-Burning Equipment & & $(2)$ \\
Small Boilers, Vaporizers, and Heating Units & $(2)$ & $(2)$ \\
Large Boilers, Vaporizers, and Heating Units & $(2)$ & $(2)$ \\
Diesel Generators & $(2)$ & $(2)$ \\
Vehicles & & $(2)$ \\
Light Construction/Mining Equipment & $(3)$ & $(2)$ \\
Heavy Construction/Mining Equipment & $(3)$ & $(2)$ \\
Small Mobile Equipment & $(3)$ & $(3)$ \\
Buses & $(1)$ Facility-Specific Preliminary Decommissioning Plans \\
\hline \hline
\end{tabular}

(1) Facility-Specific Preliminary Decommissioning Plans ${ }^{21,22,23}$

(2) Facility-Specific Annual Reports ${ }^{11,24}$

(3) Proprietary Data Provided by Facility Operator

* Data unavailable. Estimate based on materials at Key Lake/total building footprint 


\subsubsection{Operational Activities}

Table S2 summarizes the operational data requested and received for each facility. Data for McArthur River, Key Lake, and Rabbit Lake was most often available from 2006-2013 with some additional data available for earlier years. Data for McClean Lake was available from 1995-2010. For all facilities, data gaps are generally more common in early years. 
Table S2. Operational Data Requested and Received

\begin{tabular}{|c|c|c|c|c|c|}
\hline \multirow{2}{*}{ Data Requested } & \multirow{2}{*}{$\begin{array}{c}\text { Data } \\
\text { Source }\end{array}$} & \multicolumn{4}{|c|}{ Years of Data Available } \\
\hline & & McArthur River & Key Lake & Rabbit Lake & McClean Lake \\
\hline \multicolumn{6}{|l|}{ Operational Parameters } \\
\hline People on Site (man-days worked) & $(1,2)$ & 8 & 9 & 5 & 15 \\
\hline \multicolumn{6}{|l|}{ Production Data } \\
\hline Tonnes Ore Produced/Processed & $(1)$ & 14 & 13 & 8 & 16 \\
\hline $\mathrm{kg} \mathrm{U}_{3} \mathrm{O}_{8}$ Equivalents Processed/Shipped & (1) & 14 & 13 & 8 & 16 \\
\hline \multicolumn{6}{|l|}{ Energy Consumption Data } \\
\hline Electricity & $(2)$ & 8 & 9 & 8 & 11 \\
\hline Diesel & $(2)$ & 8 & 9 & 8 & 8 \\
\hline Propane & $(2)$ & 8 & 9 & 8 & 12 \\
\hline Gasoline & $(2)$ & 8 & 9 & 8 & 12 \\
\hline \multicolumn{6}{|l|}{ Transportation Data } \\
\hline Flight Schedules & $(2)$ & 8 & 7 & 7 & $0 *$ \\
\hline Freight Reports & $(2)$ & 8 & 7 & 7 & 12 \\
\hline \multicolumn{6}{|l|}{ Fugitive Emission Data } \\
\hline Domestic Wastewater Generation & $(1)$ & $0 * *$ & $0 * *$ & $0 * *$ & $0 * *$ \\
\hline Liquid/Solid Waste Generation & $(1,2)$ & 9 & 9 & 8 & 13 \\
\hline Process Emissions & (3) & & & & \\
\hline Concrete Usage (within mine) & (1) & 12 & $\mathrm{~N} / \mathrm{A}$ & 8 & $\mathrm{~N} / \mathrm{A}$ \\
\hline Reagent Consumption & (1) & 4 & 10 & 8 & 15 \\
\hline Explosive Usage & (2) & 7 & $\mathrm{~N} / \mathrm{A}$ & 7 & 16 \\
\hline
\end{tabular}

(1) Facility-Specific Annual Reports

(2) Proprietary Data Provided by Facility Operator

(3) Calculation - Direct $\mathrm{CO}_{2}$ emissions from reaction of carbonates with sulfuric acid added during milling process - carbonates present in ore and reagents - assumes $100 \%$ reaction

N/A - Not Applicable

* None available, amount estimated based on number of people on site compared to McArthur River, corrected for relative distance from Saskatoon

** Estimated assuming $255 \mathrm{~L} /$ day generation per man-day worked 


\subsubsection{Corporate Activities}

For both operators, corporate headquarters (HQ) are located in Saskatoon, SK. Emissions from fuel and electricity consumption at HQ are allocated to each mine and mill. These allocations are likely conservative as both corporations are involved with uranium mining-milling operations outside Canada.

Proprietary data for natural gas and electricity consumption at corporate headquarters was supplied from 2006-2013 by Cameco and from 2003-2013 for AREVA.

Emissions from Cameco's headquarters are allocated one quarter each to Cameco's four main SK operations: McArthur River, Key Lake, Rabbit Lake, and Cigar Lake over the time period where data is available. Emissions from AREVA's headquarters are allocated one half each to Cluff Lake and to McClean Lake.

No other emissions-relevant activities are included as they are expected to fail the $0.1 \%$ cut-off criteria. As an example, materials used in the construction of corporate buildings are excluded from analysis. The footprint of corporate buildings is very small compared to the building footprint at the mines and mills. The latter contributes less than $0.2 \%$ to the emissions total.

\subsubsection{Decommissioning}

Decommissioning activities are described in each site's Preliminary Decommissioning Plan (PDP), a document submitted to the Saskatchewan Ministry of Environment. The PDP is updated in maximum 5-year intervals. This document, and the associated Preliminary Decommissioning Cost Estimate (PDCE), contains estimates for heavy equipment use, energy consumption, major material requirements (e.g. lime, concrete), and employee transportation during decommissioning activities. 
PDP and PDCE documents are provided by Cameco for McArthur River, Key Lake, and Rabbit Lake. AREVA has provided a decommissioning plan summary for McClean Lake and a detailed decommissioning report for Cluff Lake which has been in the decommissioning phase since 2002, the last buildings demolished in 2013. Decommissioning plans at each facility are compared to decommissioning activities at Cluff Lake to ensure the reasonableness of the results.

\subsubsection{Land Use Change}

The facilities are located in the unmanaged forests of Canada's western boreal shield ecozone. ${ }^{25}$ Forest productivity is low due to long cold winters (January daily average is $\left.25^{\circ} \mathrm{C}\right)^{26}$, short cool summers (July averages $+15^{\circ} \mathrm{C}$ ), low decomposition rates and nutrient availability ${ }^{27}$, and presence of discontinuous permafrost and outcropping of Precambrian granite. The unmanaged boreal forests were assigned a pre-development net ecosystem productivity rate of $31 \mathrm{~g}-\mathrm{C} \mathrm{m}^{-2} \mathrm{yr}^{-1}$ (i.e., net carbon sink) with an uncertainty range of 20 to $40 \mathrm{~g}-\mathrm{C} \mathrm{m}^{-2} \mathrm{yr}^{-1}$. This is the net ecosystem productivity in this region between 1990 and 2008 as estimated by Stinson et al. ${ }^{28}$ Saskatchewan's managed forests are typically located further south and have higher carbon densities (i.e., $\mathrm{Mg}-\mathrm{C} \mathrm{ha}^{-1}$ ) than Saskatchewan's unmanaged western boreal shield forests (Figure 5; Kurz et al. ${ }^{27}$ ). For this reason, the net ecosystem productivity values used in this study may be conservative estimates.

During mine-mill construction, the boreal forests are cleared. During decommissioning, the mine-mill sites are reclaimed in accordance with approved decommissioning plans. During the disturbance period, the disturbed area within the mine-mills footprints is assigned a net annual carbon flux of zero (i.e., neither a sink nor 
a source) resulting in a net annual GHG emission rate of $31 \mathrm{~g}-\mathrm{C} \mathrm{m} \mathrm{yr}^{-1}$ (i.e., $1,137 \mathrm{~kg}$ $\left.\mathrm{CO}_{2} \mathrm{e} \mathrm{ha}^{-1} \mathrm{yr}^{-1}\right)$.

Increased emissions from soil carbon loss in response to forest harvesting and conversion to industrial use are not considered in the assessment. This term can likely be ignored due to low decomposition rates in this ecozone. ${ }^{27}$

The disturbance period is assumed to begin at facility construction and to end 15-years after the active decommissioning period for each facility when the area is assumed to return to net carbon compensation. ${ }^{27}$ The total disturbance period for the facilities, based on historical production and the life-of-mine plans used for this study, are 56, 67, and 75 years.

The disturbed areas for the three mine-mills are currently 410, 540, and 917 ha per mine-mill. ${ }^{21,22,23,29}$ These areas have grown over time as the facilities have expanded (e.g., new deposits are developed, waste rock and tailings areas are expanded, borrow pits are developed) and may shrink before facilities are decommissioned due to ongoing reclamation activities. The land use change emissions estimate in this study neglects these periods of growth and pre-decommissioning reclamation and so the emissions estimate may be somewhat overstated. 


\subsection{Inventory of Emissions Sources}

Operational activities for each mine-mill pair were divided by (i.e., normalized to) total $\mathrm{U}_{3} \mathrm{O}_{8}$ production during the operational periods included in the study period (2006 - 2013 for McArthur River, Key Lake, and Rabbit Lake, and 1995 - 2010 for McClean Lake). Activities at corporate headquarters during these operational periods are also included and normalized in the same way.

All of the facilities considered have experienced major production changes throughout their lives. For example, some mills have been in operation longer than the mines from which they currently source their ore. Earlier mining-milling activities involved different mining-milling methods, ore grades, and environmental and safety requirements. No data is currently available to perform a detailed PCA for these early $\mathrm{U}_{3} \mathrm{O}_{8}$ production periods.

The full construction and decommissioning periods, including upstream activities associated with equipment and infrastructure, were included in the inventory for all facilities. Construction and decommissioning activities were normalized to each facility's estimated lifetime $\mathrm{U}_{3} \mathrm{O}_{8}$ production.

Future production is uncertain as it relies on the accuracy of reserve estimates, ore grades, future uranium prices, and other environmental and socio-economic factors. It is assessed as follows: 
- Base Case

○ Development proceeds as per Life-of-Mine Plan (i.e., 100\% of proven and probable reserves are utilized)

- Worst Case

○ $70 \%$ of proven and probable reserves are utilized

- Best Case

○ $100 \%$ of proven and probable reserves are utilized

○ $50 \%$ utilization of measured, indicated, and inferred resources

- $25 \%$ increase in both reserves and resources due to future exploration

Data for reserves and resources is taken from facility technical and environmental reports. ${ }^{12,3,8}$

\subsection{Emission Factors}

Emission factors are available from a number of sources depending on the activity type. For most direct emissions, emission factors are obtained via literature review. For most upstream activities, emission factors are drawn from the ecoinvent v3.0 database. ${ }^{17}$

At a minimum, $\mathrm{CO}_{2}, \mathrm{CH}_{4}$, and $\mathrm{N}_{2} \mathrm{O}$ emissions are considered for all activities. Unit processes in the ecoinvent v3.0 database ${ }^{17}$ includes a number of other GHG releases in addition to these three. These also contribute to the total emissions estimate, but their impact is small.

Tables S3 to S6 list the unit processes and materials considered in this study along with their emission factors. The stated emission factors are mean values. In the software model, each factor is assigned a confidence interval, usually as a lognormal probability distribution. For activities that have a lot of natural variation, or where the data quality is S 16 
low, the confidence intervals are larger. When processes are well understood and consistent, the confidence intervals are smaller.

A number of assumptions have been made to estimate emission factors in the tables. Examples include using the life cycle emission factor of an industrial boiler to estimate the emission factor for a diesel generator. This type of estimate is used only with processes and materials that make a small overall contribution to the calculated results. The encoded uncertainties are adjusted to reflect this lack of precision.

This approach to estimating emission factors should not introduce large uncertainties into the model. In most cases, these estimates are extrapolations made on a mass basis. This means that the resulting estimate will include the correct mass of material and should contain relatively similar proportions of materials (e.g. both pieces are primarily steel with some copper, aluminum, rubber, etc.). The amount of energy used in fabrication and transportation are similarly scaled by mass. 
Table S3. Major Emission Factors Used in This Study - Energy, Explosives, Processes

\begin{tabular}{|c|c|c|c|c|c|c|}
\hline \multirow{2}{*}{ Process } & \multirow{2}{*}{ Unit } & \multicolumn{3}{|c|}{ Emission Factors ( $\mathrm{kg} \mathrm{CO}_{2} \mathrm{e} /$ Unit $)$} & \multirow{2}{*}{ Data Source } & \multirow{2}{*}{ Notes } \\
\hline & & Direct & Indirect & Life Cycle & & \\
\hline \multicolumn{7}{|l|}{ Energy } \\
\hline Propane Consumption & $\mathrm{L}$ & 1.54 & 0.43 & 1.97 & 32 - Direct, 17 - Indirect & upstream emissions are primarily from processing and transport \\
\hline Diesel Consumption & $\mathrm{L}$ & 2.79 & 0.58 & 3.36 & 32 - Direct, 17 - Indirect & upstream emissions are primarily from processing \\
\hline Gasoline Consumption & $\mathrm{L}$ & 2.3 & 0.66 & 2.96 & 32 - Direct, 17 - Indirect & upstream emissions are primarily from processing \\
\hline Natural Gas Consumption & $\mathrm{m}^{3}$ & 1.83 & 0.25 & 2.08 & 30 - Direct, 17 - Indirect & upstream emissions from processing, methane leakage, and flaring \\
\hline Electricity Consumption & $\mathrm{kWh}$ & & & 0.768 & & average grid mix 2004-2013 33 \\
\hline $\begin{array}{l}\text { Coal, Gas, Imports, } \\
\text { and Other }\end{array}$ & $\mathrm{kWh}$ & & & 0.987 & $\begin{array}{l}34 \text { - Combustion } \\
17 \text { - Other Emissions }\end{array}$ & $\begin{array}{l}77.7 \% \text { of SaskPower net electricity generation } 2004-2013^{33} \text {; } \\
0.940 / 0.987 \mathrm{~kg} \mathrm{CO}{ }_{2} \mathrm{e} \text { from combustion; imports assumed to be predominantly } \\
\text { coal and natural gas; other is assumed insignificant }\end{array}$ \\
\hline Hydro & $\mathrm{kWh}$ & & & 0.0072 & 35 (median value) & $19.4 \%$ of SaskPower net electricity generation $2004-2013^{33}$ \\
\hline Wind & $\mathrm{kWh}$ & & & 0.0109 & 35 (median value) & $2.9 \%$ of SaskPower net electricity generation $2004-2013^{33}$ \\
\hline Explosives & & & & & $\begin{array}{c}\text { stoichiometry - direct, } \\
17 \text { - indirect }\end{array}$ & \\
\hline $\mathrm{AN} / \mathrm{FO}$ & $\mathrm{kg}$ & 0.18 & 8.69 & 8.87 & & $94.2 \% \mathrm{wt}$ ammonium nitrate and $5.8 \% \mathrm{wt}$ fuel oil \\
\hline $\mathrm{AN} / \mathrm{FO}$ plus Inert & $\mathrm{kg}$ & 0.16 & 6.49 & 6.65 & & $60 \% \mathrm{wt}$ ammonium nitrate, $35 \% \mathrm{wt}$ carbonic acid, and $5 \% \mathrm{wt}$ fuel oil \\
\hline Emulsion-Type & $\mathrm{kg}$ & 0.19 & 8.04 & 8.23 & & $79 \% \mathrm{wt}$ ammonium nitrate, $15 \% \mathrm{wt}$ sodium nitrate, and $6 \% \mathrm{wt}$ fuel oil \\
\hline \multicolumn{7}{|l|}{ Process Emissions } \\
\hline CaCO3 Decomposition & $\mathrm{kg} \mathrm{CaCO}$ & 0.44 & & 0.44 & & based on stoichiometry of complete reaction \\
\hline $\begin{array}{l}\text { Na2CO3 Decomposition } \\
\text { Waste Disposal }\end{array}$ & $\mathrm{kg} \mathrm{Na}_{2} \mathrm{CO}_{3}$ & 0.42 & & 0.42 & & based on stoichiometry of complete reaction \\
\hline Domestic Solid Waste & $\mathrm{kg}$ & 0.62 & & 0.62 & 36 & methane emissions only; based on waste composition \\
\hline Contam. Solid Waste & $\mathrm{kg}$ & $0.08-0.62$ & & & 36 & methane emissions only; based on waste composition \\
\hline Liquid Organic Waste & $\mathrm{kg}$ & $0-30.4$ & & & 37,38 & varies based on composition, degree of degradation, degradation processes \\
\hline Domestic Wastewater & $\mathrm{m}^{3}$ & 0.462 & & 0.462 & 17 & \\
\hline Land Use Change & ha $\square$ year & & & 1137 & 28 & $\begin{array}{l}\text { reduction of existing ecosystem services (carbon sequestration) due to } \\
\text { conversion of boreal forest to industrial site; } \\
\text { assumes land at disturbed site operates as neither carbon source or sink }\end{array}$ \\
\hline
\end{tabular}


Table S4. Major Emission Factors Used in This Study - Infrastructure and Stationary Equipment

\begin{tabular}{|c|c|c|c|c|}
\hline Process & Unit & $\begin{array}{l}\text { Life Cycle Emission Factor } \\
\text { (kg CO} 2 \mathrm{e} / \text { Unit) }\end{array}$ & Data Source & Notes \\
\hline \multicolumn{5}{|l|}{ Infrastructure } \\
\hline Building, Steel Hall & $\mathrm{m}^{3}$ & 47.1 & 17 & $\begin{array}{l}\text { based on } 50 \mathrm{~m} \times 30 \mathrm{~m} \times 7 \mathrm{~m} \text { building of steel construction; direct emissions from diesel used during } \\
\text { construction; indirect emission primarily from steel, aluminum, brick production }\end{array}$ \\
\hline Reinforcing Steel & $\mathrm{kg}$ & 2.60 & 17 & \\
\hline Aluminum & $\mathrm{kg}$ & 14.7 & 17 & \\
\hline Brick & $\mathrm{kg}$ & 0.33 & 17 & \\
\hline Concrete & & & 40 - Cement, 17- Remainder & $\begin{array}{l}\text { based on concrete recipes from McArthur River - } 19 \\
\text { cement production } \sim 98 \% \text { of total emissions }\end{array}$ \\
\hline Construction & $\mathrm{m}^{3}$ & 394 & & \\
\hline Raise filling & $\mathrm{m}^{3}$ & 360 & & weighted average for several concrete types used in raise filling \\
\hline Shotcrete & $\mathrm{m}^{3}$ & 396 & & \\
\hline Grout & $\mathrm{m}^{3}$ & 711 & & \\
\hline Mud Slab & $\mathrm{m}^{3}$ & 201 & & \\
\hline \multicolumn{5}{|l|}{ Building Equipment } \\
\hline Steel, low-alloyed & $\mathrm{kg}$ & 2.40 & 17 & \\
\hline Chromium steel & $\mathrm{kg}$ & 1.36 & 17 & \\
\hline Cast Iron & $\mathrm{kg}$ & 2.21 & 17 & \\
\hline Rubber & $\mathrm{kg}$ & 3.13 & 17 & \\
\hline Polyethylene Pipe & $\mathrm{m}$ & 9.99 & 17 & $\begin{array}{l}1 \mathrm{~m} \text { length of } 200 \mathrm{~mm} \text { diameter polyethylene pipe containing } 3.15 \mathrm{~kg} \text { polyethylene, scaled up or } \\
\text { down based on relative cross sectional area of pipe material }\end{array}$ \\
\hline Industrial Furnace, $1 \mathrm{MW}$ & pc & 14,000 & 17 & $1 \mathrm{MW}$ industrial furnace, $4766 \mathrm{~kg}$; scaled up or down based on relative mass \\
\hline Boiler, 0.5 MW & $\mathrm{pc}$ & 16,600 & 17 & $\begin{array}{l}\text { based on } 0.5 \mathrm{MW} \text { boiler, } 2678 \mathrm{~kg} \text {, which, in turn is an interpolation of a } 0.1 \mathrm{MW} \text { boiler and } 1 \\
\text { MW industrial furnace ( } 589 \mathrm{~kg} \text { and } 4766 \mathrm{~kg} \text { respectively); scaled up or down based on relative } \\
\text { mass }\end{array}$ \\
\hline Diesel Generator, 1.6 MW & $\mathrm{pc}$ & 60,100 & 17 & $\begin{array}{l}\text { materials and production emissions based on } 1 \mathrm{MW} \text { Industrial furnace, scaled up by relative mass } \\
(20400 \mathrm{~kg} / 4766 \mathrm{~kg})\end{array}$ \\
\hline Fan/Blower $\left(720 \mathrm{~m}^{3} / \mathrm{hr}\right)$ & $\mathrm{kg}$ & 1120 & 17 & Based on $182 \mathrm{~kg}$ blower/heat exchanger, scaled by mass \\
\hline
\end{tabular}


Table S5. Major Emission Factors Used in This Study - Transport and Mobile Equipment

\begin{tabular}{|c|c|c|c|c|}
\hline Process & Unit & $\begin{array}{l}\text { Life Cycle Emission Factor } \\
\left(\mathrm{kg} \mathrm{CO}_{2} \mathrm{e} / \text { Unit }\right)\end{array}$ & Data Source & Notes \\
\hline \multicolumn{5}{|l|}{ Transport } \\
\hline Flights, excluding fuel & flt hr & 5.26 & 17 & Emissions from airport infra: $2.93 \mathrm{~kg} \mathrm{CO}_{2} \mathrm{e}$, aircraft production: $2.33 \mathrm{~kg} \mathrm{CO} 2 \mathrm{e}$ \\
\hline Jet Fuel & $\mathrm{L}$ & 3.07 & 17,41 & $\begin{array}{l}\text { Upstream emissions primarily from processing; } \\
\text { Jet fuel consumption varies from } 430 \text { to } 510 \mathrm{~L} / \mathrm{flt} \text { hr between sites }\end{array}$ \\
\hline \multicolumn{5}{|l|}{ Freight, Reagents, Fuel } \\
\hline 5-6 axle van/flatdeck & $\mathrm{km}$ & 1.62 & 17,32 & $\begin{array}{l}\text { Emissions from: diesel burning: } 1.33 \mathrm{~kg} \mathrm{CO} \mathrm{CO}_{2} \text {; rest is vehicle production, maint, and road infra; based } \\
\text { on } 0.47 \mathrm{~L} / \mathrm{km} \text { fuel economy } 42\end{array}$ \\
\hline 8 axle flatdeck & $\mathrm{km}$ & 2.23 & 17,32 & $\begin{array}{l}\text { Emissions from: diesel burning: } 1.49 \mathrm{~kg} \mathrm{CO} \mathrm{CO}_{2} \text {; rest is vehicle production, maint, and road infra; based } \\
\text { on } 0.523 \mathrm{~L} / \mathrm{km} \text { fuel economy } 42\end{array}$ \\
\hline 9 axle/special configs & $\mathrm{km}$ & 2.35 & 17,32 & $\begin{array}{l}\text { Emissions from: diesel burning: } 1.89 \mathrm{~kg} \mathrm{CO}_{2} \mathrm{e} \text {; rest is vehicle production, maint, and road infra; based } \\
\text { on } 0.672 \mathrm{~L} / \mathrm{km} \text { fuel economy } 42\end{array}$ \\
\hline Unknown type & $\mathrm{T}-\mathrm{km}$ & 0.0646 & 17 & $\begin{array}{l}\text { Emissions from diesel burning: } 0.0430 \mathrm{~kg} \mathrm{CO}_{2} \mathrm{e} \text {; rest is vehicle production, maint, and road infra; based } \\
\text { on 8-axle flatdeck with nominal } 34.5 \mathrm{~T} \text { cargo }\end{array}$ \\
\hline \multicolumn{5}{|l|}{ Vehicles } \\
\hline Light vehicle & $\mathrm{pc}$ & 16,100 & 17 & $\begin{array}{l}\text { production and maintenance; based on } 1524 \mathrm{~kg} \text { light duty vehicle; emission factor scaled up or down } \\
\text { based on relative vehicle weight }\end{array}$ \\
\hline Light mobile construction & $\mathrm{pc}$ & 34,300 & 17 & $\begin{array}{l}\text { production and maintenance; based on } 3000 \mathrm{~kg} \text { tractor; emission factor scaled up or down based on } \\
\text { relative vehicle weight }\end{array}$ \\
\hline Heavy mobile construction & $\mathrm{pc}$ & 83,800 & 17 & $\begin{array}{l}\text { production and maintenance; based on 15,372 } \mathrm{kg} \text { truck; emission factor scaled up or down based on } \\
\text { relative vehicle weight }\end{array}$ \\
\hline
\end{tabular}


Table S6. Major Emission Factors Used in This Study - Reagents

\begin{tabular}{|c|c|c|c|c|}
\hline Reagents & Unit & $\begin{array}{l}\text { Life Cycle Emission Factor } \\
\left(\mathrm{kg} \mathrm{CO}_{2} \mathrm{e} / \text { Unit }\right)\end{array}$ & Data Source & Notes \\
\hline Steel grinding balls & $\mathrm{kg}$ & 2.05 & 17 & \\
\hline Coagulants, flocculants, anti-scalants & $\mathrm{kg}$ & 2.14 & 17 & Modeled as 'organic chemicals' \\
\hline Sulfur & $\mathrm{kg}$ & 0.02 & 17 & \\
\hline Lime & $\mathrm{kg}$ & 0.10 & 17 & \\
\hline Kerosene & $\mathrm{kg}$ & 0.59 & 17 & \\
\hline Ammonia & $\mathrm{kg}$ & 2.07 & 17 & \\
\hline Barium Chloride & $\mathrm{kg}$ & 2.30 & 17 & Modeled as 'inorganic chemicals' \\
\hline Hydrogen Peroxide & $\mathrm{kg}$ & 1.30 & 17 & \\
\hline Citric Acid & $\mathrm{kg}$ & 28.3 & 17 & \\
\hline Potassium Permanganate & $\mathrm{kg}$ & 1.61 & 17 & \\
\hline Hydrochloric Acid (w/o water) & $\mathrm{kg}$ & 1.72 & 17 & \\
\hline Isobutanol & $\mathrm{kg}$ & 3.02 & 17 & \\
\hline Versene (EDTA) & $\mathrm{kg}$ & 4.31 & 17 & \\
\hline Sodium Hydroxide (w/o water) & $\mathrm{kg}$ & 1.38 & 17 & \\
\hline Tertiary Amine & $\mathrm{kg}$ & 3.15 & 17 & Modeled as 'triethyl amine' \\
\hline Nitrogen, Liquid & $\mathrm{kg}$ & 0.60 & 17 & \\
\hline Sodium Bicarbonate & $\mathrm{kg}$ & 0.95 & 17 & \\
\hline Sulfuric Acid & $\mathrm{kg}$ & 0.12 & 17 & \\
\hline Oxygen, Liquid & $\mathrm{kg}$ & 0.62 & 17 & \\
\hline Quicklime & $\mathrm{kg}$ & 1.09 & 17 & \\
\hline Iron Sulfate & $\mathrm{kg}$ & 0.25 & 17 & \\
\hline Magnetite & $\mathrm{kg}$ & 1.09 & 17 & \\
\hline Kerosene & $\mathrm{kg}$ & 0.59 & 17 & \\
\hline Sodium Chlorate & $\mathrm{kg}$ & 4.39 & 17 & \\
\hline
\end{tabular}




\subsection{Conversion from $\mathrm{kg} \mathrm{CO} 2 \mathrm{e} / \mathrm{kg} \mathrm{U}_{3} \mathrm{O}_{8}$ to $\mathrm{g} \mathrm{CO}_{2} \mathrm{e} / \mathrm{kWh}$}

Emission intensity estimates from the uranium mining-milling phase of the nuclear fuel cycle are generally reported as $\mathrm{g} \mathrm{CO}_{2} \mathrm{e} / \mathrm{kWh}\left(I_{k W h}\right)$ which is not directly comparable to the results of the current study $\left(I_{U_{3} O_{8}}\right.$ presented in $\left.\mathrm{kg} \mathrm{CO}_{2} \mathrm{e} / \mathrm{kg} \mathrm{U}_{3} \mathrm{O}_{8}\right)$. The final value for $I_{k W h}$ will be different depending on the type of reactor used and its operating parameters, namely burn-up $(B)$ and thermal efficiency $\left(\eta_{t h}\right)$. The yield of enriched uranium per unit of natural uranium $\left(\eta_{e n r}\right)$ is also important.

A unit conversion can be performed as follows:

$$
I_{k W h}=\frac{I_{U_{3} O_{8}}}{B \times \eta_{t h} \times \eta_{e n r}}
$$

Using an example in Fthenakis and $\mathrm{Kim}^{43}$, a light water reactor (LWR) may burn-up at $B=42 \mathrm{MW}_{\text {th }} \mathrm{d} / \mathrm{kg} \mathrm{U}$, operate at $\eta_{t h}=0.3$, and require the enrichment of $7 \mathrm{~kg} \mathrm{U}$ to generate a $1 \mathrm{~kg}$ enriched $\mathrm{U}$ fuel with $3.8 \% \mathrm{U}-235$ content $\left(\eta_{e n r}=0.1429\right)$. Using these parameters yields the following conversion factor:

$$
\frac{I_{k W h}}{I_{U_{3} O_{8}}}=2.7 \times 10^{-5} \frac{\mathrm{kg} \mathrm{U_{3 } O _ { 8 }}}{\mathrm{kWh}}
$$

Heavy water reactors (HWR) burn-up at approximately $B=8 \mathrm{MW}_{\mathrm{th}} \mathrm{d} / \mathrm{kg} \mathrm{U}$, have a similar thermal efficiency, and do not require uranium enrichment $\left(\eta_{\text {enr }}=1\right) .{ }^{44,45}$ This yields an emission intensity factor of $2.0 \times 10^{-5} \frac{\mathrm{kg} \mathrm{U_{3 } \mathrm { O } _ { 8 }}}{\mathrm{kWh}}$.

Note that these calculations required the conversion of mass $\mathrm{U}$ to $\mathrm{U}_{3} \mathrm{O}_{8}$ and $\mathrm{MWd}$ to $\mathrm{kWh}$. The factors and assumptions used in the above calculation are not always included in the studies reviewed. 


\subsection{Uncertainty}

Myriad factors introduce uncertainty to the calculated emission intensity for each facility including data gaps and uncertainty in emission factors.

Where gaps on activity data within the specified operational period exist, the uncertainty in the calculated activity factor is based on the number of years without data and the year-to-year variation of the known data using a lognormal probability distribution. The lognormal distribution was chosen because it provided a good representation of the variation in the available data. Uncertainty in operational activity data is only assessed from 2006 to 2013 for McArthur River, Key Lake, and Rabbit Lake. It is assessed from 1995 to 2010 for McClean Lake.

The $95 \%$ confidence interval used to fill data gaps for any given year is calculated as follows:

$$
95 \% C I=e^{\mu \pm 2 \sigma}
$$

where:

$$
\begin{aligned}
& \mu=\text { mean of log-transformed data } \\
& \sigma=\text { standard deviation of log-transformed data }
\end{aligned}
$$

Uncertainty is propagated to the calculated total for each activity factor using the root sum of squares method:

$$
2 \sigma_{T}=\frac{\sqrt{n(2 \sigma)^{2}}}{n_{T}}
$$

where:

$$
2 \sigma_{T}=\text { total uncertainty in summed log-transformed data }
$$


$n=$ number of years without data within specified operational period

$n_{T}=$ total number of years within specified operational period

And the overall confidence interval of the activity factor is:

$$
95 \% C I=e^{\mu \pm 2 \sigma_{T}}
$$

The uncertainty factor is encoded in SimaPro as the square of the geometric standard deviation $\left(\sigma_{g}^{2}\right)$ :

$$
\sigma_{g}^{2}=e^{2 \sigma_{T}}
$$

This method considers variation year-by-year and ignores changes in operation, production volumes, and ore grade. Inclusion of these other parameters would likely reduce the uncertainty in the result, but the calculation is not straightforward and, as will be shown in Section 3.3, is not required to produce a reasonably precise result.

When the above method cannot be applied (e.g., emission factors, infrastructure and equipment), uncertainty is assessed based on the methodology used in the SimaPro software and ecoinvent database, described in Weidema et al. ${ }^{46}$ The methodology is also endorsed in the Greenhouse Gas Protocol, which itself provides reporting standards, sector guidance, and calculation tools for quantifying and reporting GHG emissions for companies and organizations around the world. ${ }^{47}$

The probability distribution of each parameter is defined by assessing and combining six categories of uncertainty:

1. Basic Uncertainty

2. Reliability

3. Completeness

4. Temporal Correlation

5. Geographical Correlation

6. Further Technological Correlation 
The first, Basic Uncertainty, is applied in absence of sampled data. It is modeled as a lognormal probably distribution with the square of the geometric standard deviation ranging from 1 to 3 depending on the inherent uncertainty in the type of data as per Table S7.

Table S7. Basic Uncertainty Factors from Weidema et al. ${ }^{46}$

\begin{tabular}{lc}
\hline & $\begin{array}{c}\text { Basic Uncertainty Factor } \\
\mathrm{U}_{1}=\sigma_{\mathrm{g} 1}{ }^{2}\end{array}$ \\
\hline Demand of: & \\
Energy & 1.05 \\
Materials & 1.05 \\
Transport services & 2.00 \\
Infrastructure & 3.00 \\
Pollutants emitted to air: & \\
$\mathrm{CO}_{2}$ & 1.05 \\
$\mathrm{CH}_{4}$ & 1.50 \\
$\mathrm{~N}_{2} \mathrm{O}$ & 1.50 \\
\hline \hline
\end{tabular}

The other five sources of uncertainty are applied using the indicator score definitions shown in Figure S2 and their associated uncertainty factors, listed in Table S8. Figure S2 only shows definitions for the extreme values of each indicator score. Full definitions are available in Weidema et al. ${ }^{46}$ 
Indicator Score
1
ata based
Reliability
5

Verified data based
on measurements

Representative data from all sites relevant for the market considered, over an adequate period to even out normal fluctuations

\section{Completeness}

Temporal Correlation

Less than 3 years of difference to the time period of the dataset

Data from area under study

Data from enterprises, processes, and materials under study
Geographical Correlation

Further Technological Correlation
Representativeness unknown or data from a small number of sites and from shorter periods

Age of the data unknown or more than 15 years of difference to the time period of the dataset

Data from unknown or distinctly different area

Data on related processes on laboratory scale or from different technology

Figure S2. Indicator Score Range and Definitions Used in Assessing Uncertainty Factors ${ }^{46}$

Table S8. Elemental Factors Used in Assessing Total Uncertainty Factor. Reported as square of geometric standard deviation ${ }^{46}$

\begin{tabular}{lccccc}
\hline Indicator Score & 1 & 2 & 3 & 4 & 5 \\
\hline Reliability & 1.00 & 1.05 & 1.10 & 1.20 & 1.50 \\
Completeness & 1.00 & 1.02 & 1.05 & 1.10 & 1.20 \\
Temporal Correlation & 1.00 & 1.03 & 1.10 & 1.20 & 1.50 \\
Geographical Correlation & 1.00 & 1.01 & 1.02 & 1.05 & 1.20 \\
Technological Correlation & 1.00 & 1.05 & 1.20 & 1.50 & 2.00 \\
\hline \hline
\end{tabular}


Total uncertainty is calculated using the following formula:

$$
\sigma_{g}^{2}=\exp \sqrt{\left[\ln \left(U_{1}\right)\right]^{2}+\left[\ln \left(U_{2}\right)\right]^{2}+\left[\ln \left(U_{3}\right)\right]^{2}+\left[\ln \left(U_{4}\right)\right]^{2}+\left[\ln \left(U_{5}\right)\right]^{2}+\left[\ln \left(U_{6}\right)\right]^{2}}
$$

where:

$\mathrm{U}_{1}=$ basic uncertainty factor

$\mathrm{U}_{2}=$ uncertainty factor of reliability

$\mathrm{U}_{3}=$ uncertainty factor of completeness

$\mathrm{U}_{4}=$ uncertainty factor of temporal correlation

$\mathrm{U}_{5}=$ uncertainty factor of geographical correlation

$\mathrm{U}_{6}=$ uncertainty factor of further technological correlation; and

$\mathrm{U}_{\mathrm{n}}=$ the square of the element's geometric standard deviation.

The uncertainties in each parameter are propagated to the total result using the Monte Carlo method. In this method, each parameter is varied randomly within its probability distribution. The total result is calculated repeatedly based on the assigned values of its constituent parameters. With repeated calculation, a probability distribution for the total emerges. In this study, each total was calculated based on 5000 runs and a $95 \%$ confidence interval is reported.

Due to the qualitative aspect of this methodology, a confidence interval calculated in this way is not a precise value. Rather, it provides an indication of the overall uncertainty in the results and the relative uncertainty in the processes that make up the system model.

Uncertainty values for most major activity factors and emissions factors are shown in Table S9. 


\subsection{Life Cycle Inventory Data}

Activity and emission factor data have been compiled according to the methodology and sources described in Sections 2.1,2.2, 2,3, and 2.5. Table S9 summarizes the values for these factors for most major processes for the production-weighted average result (see main body of manuscript Section 5.5). In total, the activities indicated in Table S9 account for $98.8 \%$ of the life cycle GHG emissions assessed in this study.

Table S9 also indicates the level of uncertainty in the activity and emission factors presented. These uncertainties were calculated using the methodology stated in Section 2.5 and are presented as the square of the geometric standard deviation $\left(\sigma_{g}^{2}\right)$ of a lognormal probability distribution, consistent with how the factors are encoded in SimaPro. Each emission factor includes the aggregate emissions and uncertainty in all of its underlying processes. In propane consumption, for example, this includes the emissions and uncertainty during resource extraction, processing, transportation, and fuel combustion. For those emission factors taken from the ecoinvent v3.0 life cycle database ${ }^{17}$ (see Section 2.3), uncertainty data also comes from ecoinvent. 
Table S9. Life Cycle Inventory Data Including Uncertainty

\begin{tabular}{|c|c|c|c|c|c|c|c|}
\hline \multicolumn{2}{|l|}{ Process } & $\begin{array}{c}\text { Activity Factor } \\
\text { for Production- } \\
\text { Weighted } \\
\text { Average }\end{array}$ & Units & $\begin{array}{c}\text { Activity Factor } \\
\text { Uncertainty }\left(\sigma_{g}{ }^{2}\right)\end{array}$ & Emission Factor & Units & $\begin{array}{l}\text { Emission Factor } \\
\text { Uncertainty }\left(\sigma_{\mathrm{g}}{ }^{2}\right)\end{array}$ \\
\hline \multicolumn{2}{|l|}{ Electricity } & 22.0 & $\mathrm{kWh} / \mathrm{kg} \mathrm{U} \mathrm{O}_{8}$ & 1.01 & 0.768 & $\mathrm{~kg} \mathrm{CO} 2 \mathrm{e} / \mathrm{kWh}$ & 1.14 \\
\hline \multicolumn{2}{|l|}{ Propane } & 4.76 & $\mathrm{~L} / \mathrm{kg} \mathrm{U}_{3} \mathrm{O}_{8}$ & 1.00 & 1.97 & $\mathrm{~kg} \mathrm{CO}{ }_{2} \mathrm{e} / \mathrm{L}$ & 1.06 \\
\hline \multicolumn{2}{|l|}{ Diesel } & 0.968 & $\mathrm{~L} / \mathrm{kg} \mathrm{U}_{3} \mathrm{O}_{8}$ & 1.01 & 3.36 & $\mathrm{~kg} \mathrm{CO}_{2} \mathrm{e} / \mathrm{L}$ & 1.05 \\
\hline \multicolumn{8}{|c|}{ Reagent Consumption } \\
\hline- & Ammonia & 0.404 & $\mathrm{~kg} / \mathrm{kg} \mathrm{U} \mathrm{U}_{3} \mathrm{O}_{8}$ & 1.00 & 2.07 & $\mathrm{~kg} \mathrm{CO}_{2} \mathrm{e} / \mathrm{kg}$ & 1.33 \\
\hline- & Lime/Quicklime* & 2.91 & $\mathrm{~kg} / \mathrm{kg} \mathrm{U} \mathrm{U}_{3}$ & 1.00 & 0.426 & $\mathrm{~kg} \mathrm{CO}_{2} \mathrm{e} / \mathrm{kg}$ & $* *$ \\
\hline- & Hydrogen Peroxide & 0.202 & $\mathrm{~kg} / \mathrm{kg} \mathrm{U} \mathrm{U}_{3} \mathrm{O}_{8}$ & 1.08 & 1.30 & $\mathrm{~kg} \mathrm{CO} 2 \mathrm{e} / \mathrm{kg}$ & 1.23 \\
\hline \multicolumn{8}{|c|}{ Construction, Infrastructure and Equipment } \\
\hline- & Electricity & 0.894 & $\mathrm{kWh} / \mathrm{kg} \mathrm{U}_{3} \mathrm{O}_{8}$ & $* *$ & 0.768 & $\mathrm{~kg} \mathrm{CO}_{2} \mathrm{e} / \mathrm{kWh}$ & 1.14 \\
\hline- & Propane & 0.196 & $\mathrm{~L} / \mathrm{kg} \mathrm{U}_{3} \mathrm{O}_{8}$ & $* *$ & 1.97 & $\mathrm{~kg} \mathrm{CO}_{2} \mathrm{e} / \mathrm{L}$ & 1.06 \\
\hline- & Diesel & 0.0887 & $\mathrm{~L} / \mathrm{kg} \mathrm{U}_{3} \mathrm{O}_{8}$ & $* *$ & 3.36 & $\mathrm{~kg} \mathrm{CO}_{2} \mathrm{e} / \mathrm{L}$ & 1.05 \\
\hline- & Gasoline & 0.0133 & $\mathrm{~L} / \mathrm{kg} \mathrm{U}_{3} \mathrm{O}_{8}$ & $* *$ & 2.96 & $\mathrm{~kg} \mathrm{CO}_{2} \mathrm{e} / \mathrm{L}$ & 1.07 \\
\hline- & Flights to Site* & $1.52 \mathrm{E}-04$ & flt.hr/ $\mathrm{kg} \mathrm{U} \mathrm{U}_{3} \mathrm{O}_{8}$ & $* *$ & 1409 & $\mathrm{~kg} \mathrm{CO} 2 \mathrm{e} / \mathrm{flt} . \mathrm{hr}$ & 1.36 \\
\hline $\begin{array}{l}- \\
(\text { Prin }\end{array}$ & $\begin{array}{l}\text { Building Materials } \\
\text { ily steel and aluminum) }\end{array}$ & $2.17 \mathrm{E}-03$ & $\begin{array}{c}\mathrm{m}^{3} \text { building } \\
\text { volume } / \mathrm{kg} \mathrm{U}_{3} \mathrm{O}_{8}\end{array}$ & $* *$ & 47.1 & $\mathrm{kgCO}_{2} \mathrm{e} / \mathrm{m}^{3}$ & 1.57 \\
\hline \multicolumn{8}{|c|}{ Truck Transport } \\
\hline- & 5-6 axle van/flatdeck & 0.269 & $\mathrm{~km} / \mathrm{kg} \mathrm{U} \mathrm{O}_{8}$ & 1.04 & 1.62 & $\mathrm{~kg} \mathrm{CO} 2 \mathrm{e} / \mathrm{km}$ & 1.58 \\
\hline- & 8 axle flatdeck & 0.154 & $\mathrm{~km} / \mathrm{kg} \mathrm{U}_{3} \mathrm{O}_{8}$ & 1.27 & 2.23 & $\mathrm{~kg} \mathrm{CO} 2 \mathrm{e} / \mathrm{km}$ & 1.58 \\
\hline- & 9 axle/special configurations & 0.032 & $\mathrm{~km} / \mathrm{kg} \mathrm{U}_{3} \mathrm{O}_{8}$ & 1.19 & 2.35 & $\mathrm{~kg} \mathrm{CO} 2 \mathrm{e} / \mathrm{km}$ & 1.58 \\
\hline- & Unknown type (bulk) & 11.7 & T.km/kg U $\mathrm{H}_{3}$ & 1.05 & 0.0646 & $\mathrm{~kg} \mathrm{CO}{ }_{2} \mathrm{e} / \mathrm{T} . \mathrm{km}$ & 1.58 \\
\hline \multicolumn{2}{|c|}{ Flights to Site* } & $9.92 \mathrm{E}-04$ & flt.hr/kg $\mathrm{U}_{3} \mathrm{O}_{8}$ & 1.13 & 1431 & $\mathrm{~kg} \mathrm{CO} 2 \mathrm{e} / \mathrm{flt} . \mathrm{hr}$ & 1.36 \\
\hline \multicolumn{2}{|c|}{ Concrete Production* } & $3.75 \mathrm{E}-03$ & $\begin{array}{c}\mathrm{m}^{3} / \mathrm{kg} \mathrm{U}_{3} \mathrm{O}_{8} \\
\text { (all types) }\end{array}$ & 1.00 & 381 & $\mathrm{~kg} \mathrm{CO}{ }_{2} \mathrm{e} / \mathrm{m}^{3}$ & $* *$ \\
\hline
\end{tabular}

* Emission factor varies between sites. Value given is weighted average.

** Uncertainty included in assessment, but not possible to disaggregate 
Table S9 cont. Life Cycle Inventory Data Including Uncertainty

\begin{tabular}{|c|c|c|c|c|c|c|c|}
\hline Process & & $\begin{array}{c}\text { Activity Factor } \\
\text { for Production- } \\
\text { Weighted } \\
\text { Average } \\
\end{array}$ & Units & $\begin{array}{c}\text { Activity Factor } \\
\text { Uncertainty }\left(\sigma_{\mathrm{g}}{ }^{2}\right)\end{array}$ & $\begin{array}{l}\text { Emission } \\
\text { Factor }\end{array}$ & Units & $\begin{array}{l}\text { Emission Factor } \\
\text { Uncertainty }\left(\sigma_{g}{ }^{2}\right)\end{array}$ \\
\hline \multicolumn{8}{|c|}{ Use of Explosives } \\
\hline- & $\mathrm{AN} / \mathrm{FO}$ & $2.76 \mathrm{E}-02$ & $\mathrm{~kg} / \mathrm{kg} \mathrm{U_{3 } \mathrm { O } _ { 8 }}$ & 1.00 & 8.87 & $\mathrm{~kg} \mathrm{CO}_{2} \mathrm{e} / \mathrm{kg}$ & 1.47 \\
\hline- & AN/FO plus Inert & $2.25 \mathrm{E}-02$ & $\mathrm{~kg} / \mathrm{kg} \mathrm{U} \mathrm{U}_{3} \mathrm{O}_{8}$ & 1.11 & 6.65 & $\mathrm{~kg} \mathrm{CO}_{2} \mathrm{e} / \mathrm{kg}$ & 1.40 \\
\hline- & Emulsion-Type & 4.11E-02 & $\mathrm{kg} / \mathrm{kg} \mathrm{U} \mathrm{U}_{3} \mathrm{O}_{8}$ & 1.05 & 8.23 & $\mathrm{~kg} \mathrm{CO}_{2} \mathrm{e} / \mathrm{kg}$ & 1.43 \\
\hline \multicolumn{8}{|c|}{ Process Emissions } \\
\hline- & $\mathrm{CaCO}_{3}$ Decomposition & 1.43 & $\mathrm{~kg} \mathrm{CaCO}_{3} / \mathrm{kg} \mathrm{U}_{3} \mathrm{O}_{8}$ & $* *$ & 0.440 & $\mathrm{~kg} \mathrm{CO}{ }_{2} \mathrm{e} / \mathrm{kg}$ & 1.00 \\
\hline- & $\mathrm{Na}_{2} \mathrm{CO}_{3}$ Decomposition & 4.49E-02 & $\mathrm{kg} \mathrm{Na}_{2} \mathrm{CO}_{3} / \mathrm{kg} \mathrm{U}_{3} \mathrm{O}_{8}$ & 1.07 & 0.420 & $\mathrm{~kg} \mathrm{CO}{ }_{2} \mathrm{e} / \mathrm{kg}$ & 1.00 \\
\hline \multicolumn{8}{|c|}{ Decommissioning } \\
\hline- & Electricity & 4.98E-01 & 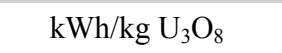 & $* *$ & 0.768 & $\mathrm{~kg} \mathrm{CO}{ }_{2} \mathrm{e} / \mathrm{kWh}$ & 1.14 \\
\hline- & Propane & $2.23 \mathrm{E}-02$ & $\mathrm{~L} / \mathrm{kg} \mathrm{U}_{3} \mathrm{O}_{8}$ & $* *$ & 1.97 & $\mathrm{~kg} \mathrm{CO}_{2} \mathrm{e} / \mathrm{L}$ & 1.06 \\
\hline- & Diesel & 4.44E-02 & $\mathrm{L} / \mathrm{kg} \mathrm{U}_{3} \mathrm{O}_{8}$ & $* *$ & 3.36 & $\mathrm{~kg} \mathrm{CO}_{2} \mathrm{e} / \mathrm{L}$ & 1.05 \\
\hline \multicolumn{8}{|l|}{ Wastes } \\
\hline- & Domestic Solid Waste & 0.122 & $\mathrm{~kg} / \mathrm{kg} \mathrm{U} \mathrm{U}_{3} \mathrm{O}_{8}$ & $* *$ & 0.620 & $\mathrm{~kg} \mathrm{CO}{ }_{2} \mathrm{e} / \mathrm{kg}$ & $* *$ \\
\hline- & Contaminated Solid Waste* & 0.404 & $\mathrm{~kg} / \mathrm{kg} \mathrm{U} \mathrm{U}_{3} \mathrm{O}_{8}$ & $* *$ & 0.343 & $\mathrm{~kg} \mathrm{CO}_{2} \mathrm{e} / \mathrm{kg}$ & $* *$ \\
\hline- & Liquid Organic Waste* & 0.168 & $\mathrm{~kg} / \mathrm{kg} \mathrm{U} \mathrm{U}_{3} \mathrm{O}_{8}$ & $* *$ & 2.37 & $\mathrm{~kg} \mathrm{CO}_{2} \mathrm{e} / \mathrm{kg}$ & $* *$ \\
\hline- & Domestic Wastewater & $8.31 \mathrm{E}-03$ & $\mathrm{~m}^{3} / \mathrm{kg} \mathrm{U_{3 } \mathrm { O } _ { 8 }}$ & 3.01 & 0.462 & $\mathrm{~kg} \mathrm{CO}{ }_{2} \mathrm{e} / \mathrm{m}^{3}$ & 1.60 \\
\hline Gasoline & & 0.127 & $\mathrm{~L} / \mathrm{kg} \mathrm{U}_{3} \mathrm{O}_{8}$ & 1.01 & 2.96 & $\mathrm{~kg} \mathrm{CO}_{2} \mathrm{e} / \mathrm{L}$ & 1.07 \\
\hline \multicolumn{8}{|c|}{ Corporate Headquarters } \\
\hline- & Electricity & 0.263 & $\mathrm{kWh} / \mathrm{kg} \mathrm{U}_{3} \mathrm{O}_{8}$ & $* *$ & 0.768 & $\mathrm{~kg} \mathrm{CO}{ }_{2} \mathrm{e} / \mathrm{kWh}$ & 1.14 \\
\hline - & Natural Gas & $3.07 \mathrm{E}-02$ & $\mathrm{~m}^{3} / \mathrm{kg} \mathrm{U} \mathrm{U}_{3} \mathrm{O}_{8}$ & $* *$ & 2.08 & $\mathrm{~kg} \mathrm{CO} 2 \mathrm{e} / \mathrm{m}^{3}$ & 1.06 \\
\hline Land Use C & & $2.33 \mathrm{E}-04$ & ha.yr $/ \mathrm{kg} \mathrm{U}_{3} \mathrm{O}_{8}$ & 1.05 & 1137 & $\mathrm{~kg} \mathrm{CO}_{2}$ e/ha.yr & 1.44 \\
\hline
\end{tabular}

* Emission factor varies between sites. Value given is weighted average.

** Uncertainty included in assessment, but not possible to disaggregate 
3 Supporting Results

Table S10 shows the GHG emission intensity for each facility by process.

Table S10. GHG Emissions Intensity $\left(\mathrm{kg} \mathrm{CO}_{2} \mathrm{e} / \mathrm{kg} \mathrm{U}_{3} \mathrm{O}_{8}\right)$ by Facility and Process

\begin{tabular}{|c|c|c|c|c|}
\hline & $\begin{array}{l}\text { Mine- } \\
\text { Mill A }\end{array}$ & $\begin{array}{l}\text { Mine- } \\
\text { Mill B }\end{array}$ & $\begin{array}{l}\text { Mine- } \\
\text { Mill C }\end{array}$ & $\begin{array}{l}\text { Production- } \\
\text { Weighted } \\
\text { Average }\end{array}$ \\
\hline Average Ore Grade $\left(\% \mathrm{U}_{3} \mathrm{O}_{8}\right)$ & 0.74 & 1.54 & 4.53 & 3.81 \\
\hline \multicolumn{5}{|l|}{ Process } \\
\hline Electricity & 36.4 & 18.2 & 13.6 & 16.9 \\
\hline Propane & 19.7 & 15.6 & 7.1 & 9.4 \\
\hline Diesel & 6.4 & 7.3 & 2.3 & 3.3 \\
\hline Reagent Consumption & 3.1 & 9.0 & 1.8 & 2.6 \\
\hline Construction, Infrastructure and Equipment & 3.7 & 0.5 & 1.9 & 2.0 \\
\hline Truck Transport & 3.1 & 2.6 & 1.3 & 1.6 \\
\hline Flights to Site & 3.0 & 2.3 & 1.1 & 1.4 \\
\hline Concrete Production* & 0.4 & 0.0 & 1.7 & 1.4 \\
\hline Use of Explosives & 1.0 & 6.5 & 0.1 & 0.7 \\
\hline Process Emissions & 0.7 & 0.4 & 0.7 & 0.6 \\
\hline Decommissioning & 1.8 & 0.1 & 0.4 & 0.6 \\
\hline Wastes & 0.7 & 0.1 & 0.7 & 0.6 \\
\hline Gasoline & 0.7 & 0.6 & 0.3 & 0.4 \\
\hline Corporate Headquarters & 0.5 & 0.2 & 0.2 & 0.3 \\
\hline Land Use Change & 0.4 & 0.2 & 0.2 & 0.3 \\
\hline Total $\left(\mathrm{kg} \mathrm{CO} \mathrm{C}_{2} / \mathrm{kg} \mathrm{U} \mathrm{U}_{3}\right)$ & 81 & 64 & 34 & 42 \\
\hline Total $\left(\mathrm{g} \mathrm{CO}_{2} \mathrm{e} / \mathrm{kWh}-\mathrm{LWR}\right)$ & 2.2 & 1.7 & 0.91 & 1.1 \\
\hline
\end{tabular}

* concrete used in mining, not in infrastructure 


\subsection{Correlations}

Shown in Figure $\mathrm{S} 3$, is the negative correlation $(\mathrm{N}=28 ; \mathrm{r}=-0.727)$ between annual emissions from energy consumption and ore-grade. This trend reflects the reduced energy expenditure required to obtain the same quantity of uranium from ores of higher grade. This correlation is complicated by the differences in the grade of ore mined compared to what enters the milling circuit in any given year.

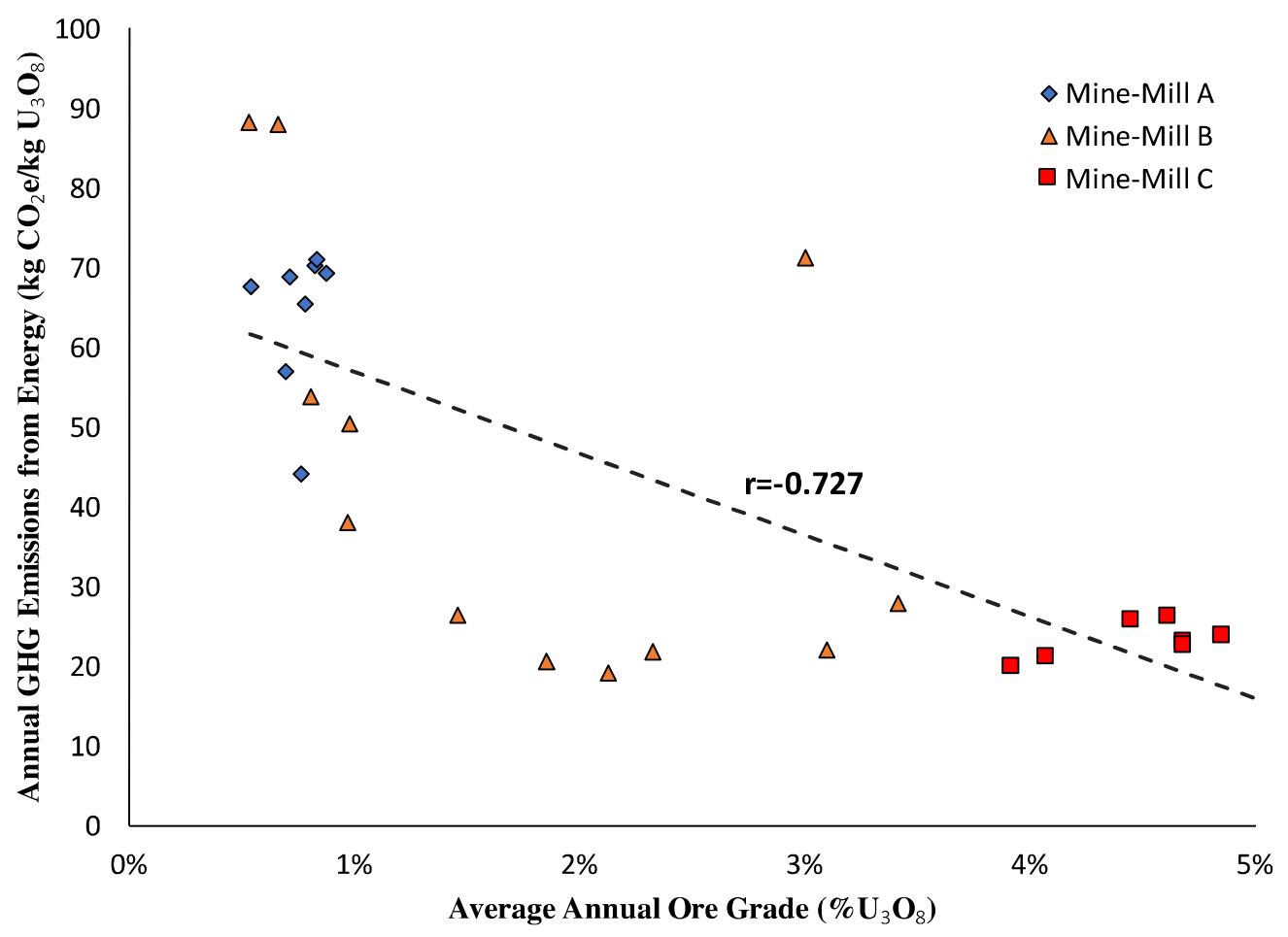

Figure S3. Annual GHG Emissions from Energy 
Emissions from reagent consumption, Figure S4, correlate weakly with the average annual ore grade entering the milling circuit $(\mathrm{N}=28, \mathrm{r}=-0.480)$. Differences at the same mill and among the mills reflect differences in ore grade and extraction processes.

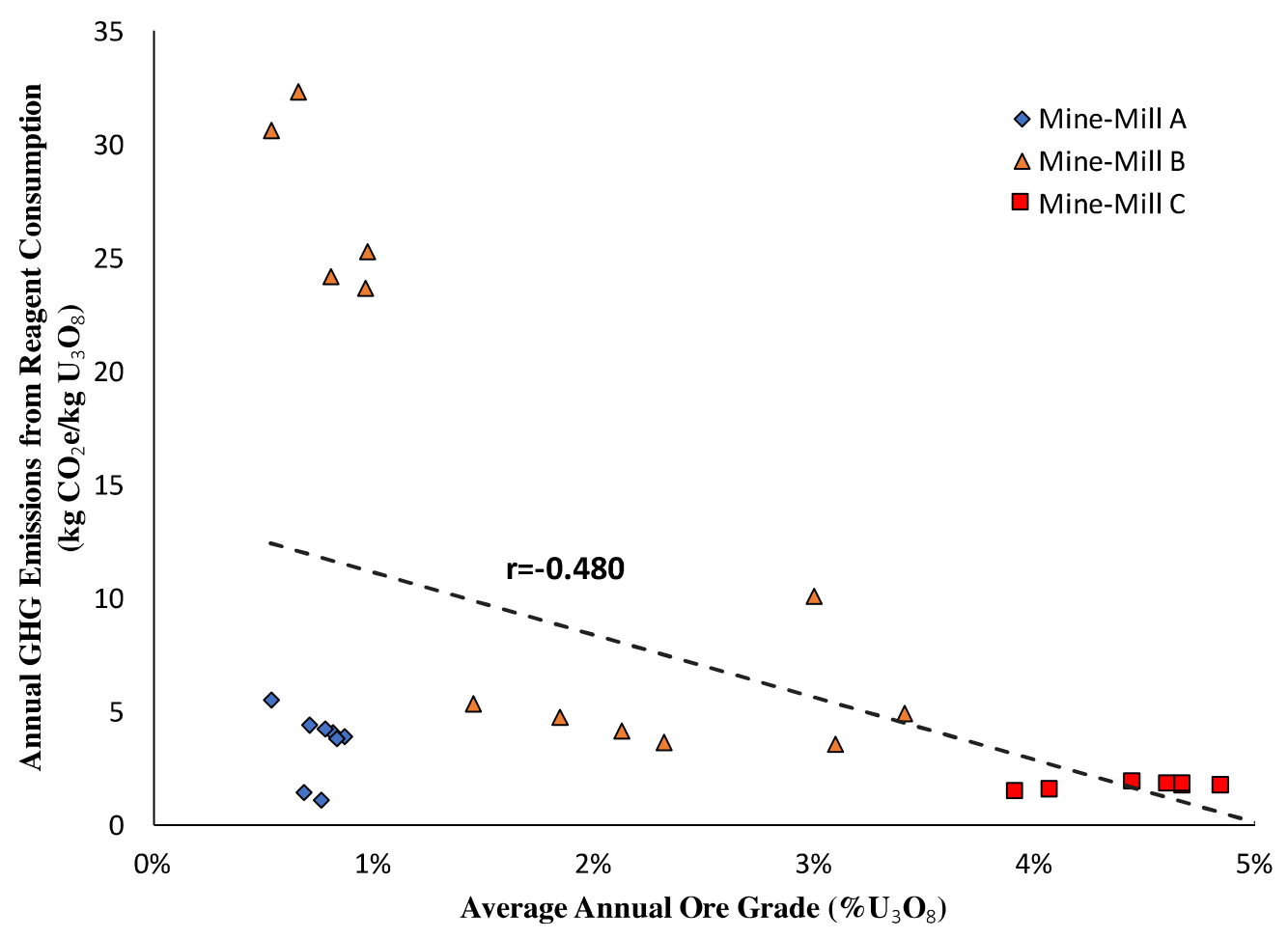

Figure S4. Annual GHG Emissions from Reagent Consumption 


\section{List of References for Supporting Information}

1. Google Maps; https://www.google.ca/maps/ (accessed September 18, 2014).

2. Cameco Corporation. McArthur River Operation Annual Report; Saskatoon, 2013.

3. Cameco Corporation. McArthur River Technical Report; Saskatoon, 2012.

4. Cameco Corporation. Key Lake Operation Annual Report; 2013.

5. Cameco Corporation. McArthur River \& Key Lake MD\&A; 2012.

6. Cameco Corporation. Operations \& Major Projects; http://www.cameco.com/northernsk/cameco in north/operation major projects/ (accessed September 18, 2014).

7. Cameco Corporation. Uranium Operations Factsheet, 2013a. Factsheets \& Publications; http://www.cameco.com/media/factsheets and publications/ (accessed December 16, 2013).

8. Cameco Corporation. Rabbit Lake Operation Annual Report; 2013.

9. Cameco Corporation. 2014 Q4 MD\&A; 2015.

10. AREVA Resources Canada Inc. Operations: McClean Lake; http://us.areva.com/EN/home-978/areva-resources-canand-activities.html (accessed September 18, 2014).

11. AREVA Resources Canada Inc. McClean Lake Operation Annual Reports;, 19952010.

12. Cameco Corporation. Cigar Lake Project; Technical Report; 2012.

13. AREVA Resources Canada Inc. Cluff Lake Project 2013 Annual Report; 2014.

14. Cameco Corporation. News Release: "First Uranium Concentrate Produced from Ore Mined at Cigar Lake"; October 8, 2014.

15. SRC - Project CLEANS; http://www.src.sk.ca/about/featuredprojects/pages/project-cleans.aspx (accessed December 3, 2014).

16. McBain, L. Uranium City; http://esask.uregina.ca/entry/uranium city.html (accessed December 3, 2014).

17. ecoinvent Centre. ecoinvent data v3.0; Swiss Centre for Life Cycle Inventories: Dübendorf, 2013.

18. Cameco Corporation. McArthur River Operation, Key Lake Operation, and Rabbit Lake Operation Annual Reports; 2001-2013.

19. Cameco Corporation. Company-Supplied Data; 2014. 
20. Cameco Corporation. Millennium Project Environmental Impact Statement; 2013.

21. Cameco Corporation. McArthur River Operation: Preliminary Decommissioning Plan; 2013.

22. Cameco Corporation. Key Lake Preliminary Decommissioning Report; 2013.

23. Cameco Corporation. Rabbit Lake Preliminary Decomissioning Plan; 2013.

24. Cameco Corporation. McArthur River Operatio, Key Lake Operation, and Rabbit Lake Operation Annual Reports; 2001-2013.

25. Natural Resources Canada (NRCan), Forest Classification; http://www.nrcan.gc.ca/forests/measuring-reporting/classification/13179 (accessed March 31, 2016).

26. Environment Canada. Canadian Climate Normals: Stone Rapids A, Saskatchewan; http://climate.weather.gc.ca/climate_normals/index_e.html (accessed March 31, 2016).

27. Kurz, W. A.; Shaw, C. H.; Boisvenue, C.; Stinson, G.; Metsaranta, J.; Leckie, D.; Dyk, A.; Smyth, C.; Neilson, E. T. Carbon in Canada's boreal forest - A Synthesis. Environmental Reviews 2013, 21 (4), 260-292.

28. Stinson, G.; Kurz, W. A.; Smyth, C. E.; Neilson, E. T.; Dymond, C. C.; Metsaranta, J. M.; Boisvenue, C.; Rampley, G. J.; Li, Q.; White, T. M.; Blain, D. An inventory-based analysis of Canada's managed forest carbon dynamics, 1990 to 2008. Global Change Biology 2011, 17, 2227-2244, doi:10.1111/j.13652486.2010.02369.x.

29. Google Earth Pro V 7.1.2.2041. Image date: 4/9/2013. Image Coordinates: $58^{\circ} 06^{\prime} 09^{\prime \prime} \mathrm{N}, 104^{\circ} 35^{\prime} 24^{\prime \prime W}$. Eye alt. $178 \mathrm{~km}$.

30. Bergeron, O.; Margolis, H. A.; Coursolle, C.; Giasson, M.-A. How does forest harvest influence carbon dioxide fluxes of black spruce ecosystems in eastern North America? Agricultural and Forest Meteorology 2008, 148 (4), 537-548, http://dx.doi.org/10.1016/j.agrformet.2007.10.012.

31. Stocks, B. J.; Mason, J. A.; Todd, J. B.; Bosch, E. M.; Wotton, B. M.; Amiro, B. D.; Flannigan, M. D.; Hirsch, K. G.; Logan, K. A.; Martell, D. L.; Skinner, W. R. Large forest fires in Canada, 1959-1997. J. Geophys. Res. 2002, 107, 8149, doi:10.1029/2001JD000484.

32. Environment Canada. GHG Emissions Quantification Guidance; http://www.ec.gc.ca/ges-ghg/default.asp?lang=En\&n=AC2B7641-1 (accessed Sept 17, 2014).

33. SaskPower. Annual Report;, 2013. 
34. Saskpower. Email Communication; 2014.

35. NREL. Life Cycle Assessment Harmonization Project; http://en.openei.org/apps/LCA/ (accessed March 5, 2014).

36. Emcon Associates. Methane Generation and Recovery from Landfills; Ann Arbor Science: Ann Arbor, Michigan, 1980.

37. Buswell, A. M.; Mueller, H. F. Mechanism of Methane Fermentation. Industrial \& Engineering Chemistry 1952, 44 (3), 550-552.

38. Riser-Roberts, E. Remediation of Petroleum Contaminated Soils; CRC Press LLC: Boca Raton, Florida, US, 1998.

39. Gower, S. T.; Krankina, O.; Olson, R. J.; Apps, M.; Linder, S.; Wang, C. Net primary production and carbon allocation patterns of boreal forest ecosystems. Ecological Applications 2001, 11 (5), 1395-1411.

40. Marceau, M. L.; Nisbet, M. A.; VanGeem, M. G. Life Cycle Inventory of Portland Cement Manufacture ; Portland Cement Association, 2006, http://www.nrmca.org/taskforce/Item 2 TalkingPoints/Sustainability/Sustainabilit y/SN2095b\%20-\%20Cement\%20LCI\%202006.pdf.

41. EPA - Greenhouse Gas Inventory Data Explorer; http://www.epa.gov/climatechange/ghgemissions/inventoryexplorer/\#electricitygen eration/allgas/source/current (accessed November 25, 2014).

42. Dalshaug, R. Operations Manager, Northern Resource Trucking; 2014, Personal Communication.

43. Fthenakis, V. M.; Kim, H. C. Greenhouse-gas emissions from solar electric- and nuclear power: A life-cycle study. Energy Policy 2007, 35, 2549-2557.

44. Andseta, S.; Thompson, M. J.; Jarrell, J. P.; Pendegrast, D. R. CANDU reactors and greenhouse gas emissions. Proceedings of the 19th Annual Conference, Canadian Nuclear Society, Toronto, Ontario, Canada, 1998.

45. Wilk, L. CANDU Fuel Burnup and Power Rating 2012 Update; Nuclear Waste Management Organization: Toronto, 2013.

46. Weidema, B. P.; Bauer, C.; Hischier, R.; Mutel, C.; Nemecek, T.; Reinhard, J.; Vadenbo, C. O.; Wernet, G. Overview and Methodology: Data Quality Guideline for the ecoinvent Database Version 3; Swiss Centre for Life Cycle Inventories, 2013

47. WRI/WBCSD. Greenhouse Gas Protocol; http://www.ghgprotocol.org/ (accessed December 11, 2014). 